Florida International University FIU Digital Commons

2012

\title{
Injustice Everywhere: Hemingway's Struggle with Race, Gender, and Aesthetics
}

Michael Riobueno

Florida International University, mriob001@fiu.edu

DOI: $10.25148 /$ etd.FI12120402

Follow this and additional works at: https://digitalcommons.fiu.edu/etd

\section{Recommended Citation}

Riobueno, Michael, "Injustice Everywhere: Hemingway's Struggle with Race, Gender, and Aesthetics" (2012). FIU Electronic Theses and Dissertations. 763.

https://digitalcommons.fiu.edu/etd/763

This work is brought to you for free and open access by the University Graduate School at FIU Digital Commons. It has been accepted for inclusion in FIU Electronic Theses and Dissertations by an authorized administrator of FIU Digital Commons. For more information, please contact dcc@fiu.edu. 


\title{
FLORIDA INTERNATIONAL UNIVERSITY \\ Miami, Florida
}

\section{INJUSTICE EVERYWHERE: ERNEST HEMINGWAY'S STRUGGLE WITH RACE, GENDER, AND AESTHETICS}

\author{
A thesis submitted in partial fulfillment of the \\ requirements for the degree of \\ MASTER OF ARTS \\ in \\ ENGLISH \\ by
}

Michael Riobueno 
To: Dean Kenneth Furton

College of Arts and Sciences

This thesis, written by Michael Riobueno, and entitled Injustice Everywhere:

Hemingway's Struggle with Race, Gender, and Aesthetics, having been approved in respect to style and intellectual content, is referred to you for judgment.

We have read this thesis and recommend that it be approved.

$\begin{array}{r}\text { Phillip L. Marcus } \\ \hline \text { Ana Luszczynska } \\ \hline \text { Nathaniel Cadle, Major Professor }\end{array}$

Date of Defense: November 6, 2012

The thesis of Michael Riobueno is approved.

$\begin{array}{r}\begin{array}{r}\text { Dean Kenneth G. Furton } \\ \text { College of Arts and Sciences }\end{array} \\ \hline \begin{array}{r}\text { Dean Lakshmi N. Reddi } \\ \text { University Graduate School }\end{array}\end{array}$

Florida International University, 2012 


\section{DEDICATION}

I would like to dedicate this thesis to Phillip L. Marcus, for constantly encouraging and facilitating my intellectual pursuits through my Undergraduate career and inspiring me to proceed in this field of study. 


\section{ACKNOWLEDGMENTS}

I would like to thank my committee for guiding me through this process, and especially

Dr. Nathaniel Cadle and Dr. Ana Luszczynska for assisting me in creating order out of what was at times chaos. 


\begin{abstract}
OF THE THESIS
INJUSTICE EVERYWHERE: HEMINGWAY'S STRUGGLE WITH RACE, GENDER, AND AESTHETICS

by

Michael Riobueno
\end{abstract}

Florida International University, 2012

Miami, Florida

Professor Nathaniel Cadle, Major Professor

The purpose of this study was to critically evaluate the aesthetic decisions and theoretical complexity of three of Ernest Hemingway's most experimental texts: IN OUR TIME, TO HAVE AND HAVE NOT, and THE GARDEN OF EDEN, and to show that the usually maligned Hemingway was an author invested in the avant-garde and in analyzing and dissecting rigid societal rules, not championing them.

Through critical analysis this study examined how Hemingway makes specific aesthetic decisions in order to more clearly examine the disparity between whites and both women and racial minorities in America. The problems that Hemingway makes clear through his art are meant to have a profound effect upon the reader and encourage re-evaluation of societal rules, their purpose, and their fairness to those who are not white, male, and typically in a position of power. The findings demonstrate that Hemingway's entire oeuvre is open to re-interpretation on the basis of a progressive view of the author. 


\section{TABLE OF CONTENTS}

CHAPTER

PAGE

INTRODUCTION .........................................................

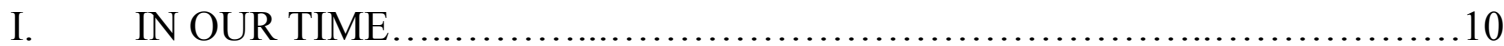

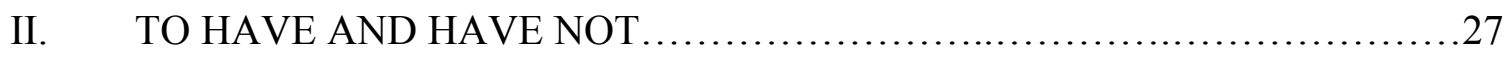

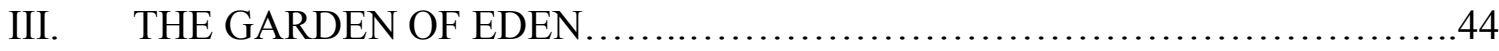

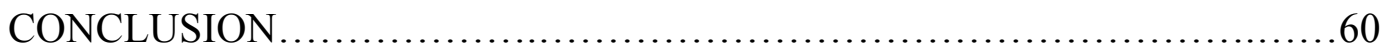

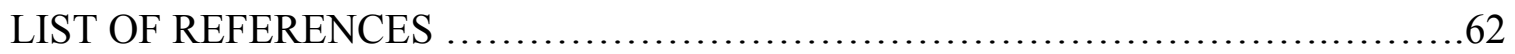




\section{INTRODUCTION}

Ernest Hemingway and the white, male characters he crafted have become synonymous with Canonical literature's misogyny, racism, and in general a troublingly nonexistent concern for minorities, or anyone that is not white and male. This lack of concern with the plight of underrepresented people in American society has, as a whole, usually been attributed to the author as well. In fact, Hemingway's lack of concern for "others" has been taken on faith for so long that Nobel Prize-winning author and critic Toni Morrison notes in surprise that the few black characters in Hemingway's fiction sometimes serve to “articulate the narrator's doom and gainsay the protagonist-narrator's construction of himself... We are left, as readers, wondering what to make of such prophecies, these slips of the pen, these clear and covert disturbances" (84). Morrison goes on to read in Hemingway's work a troubling trend of not giving a voice to minorities, be they of another race or of the female gender.

Those moments that do not conform to what Morrison calls a master narrative (of white superiority and black inferiority) are understood by her to be slips, or mistakes. However, I see a trend in Hemingway's fiction dating back to his first volume of short stories, entitled In Our Time, and continuing through his posthumously published Garden of Eden, that not only probes issues of racial and gender inequality in American society, but actively attempts to subvert these systems of thought, or, to use the language popularized by French deconstructionist Jacques Derrida, to break the binary relationship of Western metaphysical thought, and in doing so reversing (or at the very least encouraging further analysis of) the negative light cast on terms like "female" and 
"black" in relation to the terms "male" and "white." Labeling the ambiguity and theoretically rich landscape of Hemingway's texts as a "slip of the pen" (as many critics have in some way claimed) because they do not align with the man's own carefully cultivated, well-known persona is encouraging a shallow view of and critical approach to his work. My thesis will reveal that these "slips of the pen" were conscious aesthetic decisions and were written by an author invested in examining social constructs and transgressing against those constructs.

In Cosmopolitan Vistas: American Regionalism and Literary Value, critic Tom Lutz argues for a reconsideration of the aesthetic in literary criticism. Lutz suggests that the aesthetics of a text have been somewhat ignored since New Criticism and Formalism became less viable avenues of scholarship. However, he posits that a return to contemplating the aesthetic is fruitful because certain texts continually intrigue critics: "Claims of aesthetic value are often mentioned in passing, as if it were negligible to the act of recovery, cataloguing, and explication. But critics do, in fact, continue to find one text more compelling than another..." (22) Here Lutz mentions what he views as the troubling lack of concern with aesthetics in literary criticism. In so doing, Lutz is arguing for aesthetic considerations in critical evaluations of literature. Lutz then both clarifies and complicates his position that both the aesthetics and politics of a work are equally important in understanding the literary as literary:

The texts to which even the most historically- and socially-minded literary critics are continually drawn, and to which students respond, are those that are the opposite of the soapbox diatribe or the inadvertent confession, 
those in which the political consciousness and the political unconscious are complicated, to say the least. Locating that set of complications becomes impossible if the task is to identify the text's hegemonic or resistant force alone, and identifying a combination of these two forces in the text, only to conclude that the text has something like a political double consciousness, still misses the point...It does not matter if one avoids the bloody crossroads in an attempt to ignore the aesthetic or in an attempt to steer clear of the political. Either way, one loses the literary. The literary lives at the crossroads. (23)

In other words, Lutz asserts that, while critics and readers tend to respond to works that are complex in their analysis or representation of societal/political paradigms (rather than simply one-sided, like a diatribe), it is incorrect to use critical analyses strictly to interact with terms associated with New Criticism, like "complexity, ambiguity, density, and paradox" (22). Lutz claims that to analyze a text in this New Critical approach (which is more concerned with the aesthetic, or social representation) and to ignore the opposite, political side of a text, or even to hold the political and the aesthetic as separate entities within the same work, is to lose sight of the literature itself, which is a mélange of both aesthetics and politics. My exploration of Ernest Hemingway's fiction will involve aesthetic evaluation, which is something that has become rather foreign to Hemingway criticism, because the author is now almost universally seen as a "simple" writer and analyzing the aesthetics of a consciously simply-worded text has not been a priority for critics. 
Though aesthetics will be a priority in my subsequent chapters, it would be remiss to ignore the biographical aspect of the Hemingway criticism. Hemingway's troublingly misogynistic characters have resulted in an understanding of the author himself as being misogynistic and possibly racist. However, Lutz makes a good argument for looking beyond the troubling aspects of an author's personal life to analyze the value in the art (the literary) itself. Lutz acknowledges Henry James' troubling views on immigration and his anti-Semitism and Theodore Dreiser's engagement with the theoretically empty chemism, but offers James' aesthetic skill as a reason to look beyond the personal:

Both James and Dreiser do the voices of people across an array of social positions, mimicking the speech of their several microclasses, and both offer their readers a kind of contested equilibrium or unresolved resolution in the storm of competing voices and values. The 'effect of the real' they achieve, their wit, their affective power, and many other elements of their literary art are enabled by this multiplicity, this openness... Literature enacts, in its cosmopolitanism, an advertisement for its own value. (13-4)

Again, it is the author's aesthetics that create a cosmopolitan element that gives value to the text that extends beyond any particular author's unfortunate worldviews. What Lutz means by literary cosmopolitanism is "an ethos of representational inclusiveness, of the widest possible affiliation, and concurrently one of aesthetic discrimination and therefore exclusivity" (3). In this project, therefore, I am not interested in whether Ernest Hemingway was a "bad" man, a racist, a chauvinist, and a womanizer, as much biographical criticism of the author has thrived upon analyzing. I am interested in the 
aesthetic and political aspect of his work simply because Hemingway seems to have become an author who is no longer considered as aesthetically progressive or politicallyminded as many of his Modernist counterparts. There is a representational inclusiveness in Hemingway, but it is not concerned with microclasses. The inclusiveness involves representing those that have been neglected or ignored in society for biological reasons, namely gender and race, but also because of homosexual feelings during a historical period where heteronormativity reigned.

In Bodies that Matter, Judith Butler attempts to negotiate the constructedness of societal roles. She asserts that "the materiality of sex is constructed through a ritualized repetition of norms" (Bodies ix). In other words, Butler argues that we understand our bodies and genders through certain actions that we take, and these actions are socially dictated norms. Butler pursues this line of thought further and claims that:

Thinking the body as constructed demands a rethinking of the meaning of construction itself. And if certain constructions appear constituitive, that, is, have this character of being that 'without which' we could not think at all, we might suggest that bodies only appear, only endure, only live within the productive constraints of certain highly gendered regulatory schemas" (x).

Hemingway's work exhibits a marked investment in exploring the constraints of highly gendered regulatory schemas inasmuch as there is a persistent concern with gender and gender roles throughout his oeuvre. Butler is concerned with what constitutes gender in repetitive actions that bodies take, and I argue that Hemingway consistently examines 
this problem of gender construction in his most experimental fiction. From his earliest published work, we see a tradition of gender blurring and males doing "normally" female actions and females doing "normally" male actions. In this thesis, I argue that some of Hemingway's stories are concerned with this same problem of socially dictated repetition of action not only in terms of gender, but also in terms of race, and seem to suggest an interest in deconstructing racial constructs. In focusing on Hemingway's conscious blurring of societal roles, I will explore issues of gender and race in three of Hemingway's novels.

In plotting out her own views on what she sees as American literary appropriation of Africanism, or how American authors have used African identity and culture within their own texts, Morrison states that she is interested in “...How Africanist language practices are employed to evoke the tension between speech and speechlessness... to reinforce class distinctions and otherness as well as to assert privilege and power" (52). In my first chapter, I argue that Hemingway inverts this dynamic in his short story "The Battler." The character Bugs does not speak in the manner of a stereotypically "black" character; instead Bugs speaks extremely refined, typically "white” English. In making Bugs speak this way, Hemingway does the opposite of what Morrison states above. By effectively negating the language that would make Bugs an Other, in this case an Other of a different race, Hemingway forces both Nick, the protagonist and witness to the story's events, and by extension the reader, to analyze societal views on what the difference between a black person and a white person really is. 
In my second chapter, I will also focus on To Have and Have Not, a 1937 novel that is often overlooked in Hemingway scholarship because it emerged during a period when the quality of Hemingway's literary output had arguably begun to wane. However, I argue that the aesthetics of the novel alone should revive scholarly interest. Next to In Our Time, To Have and Have Not is Hemingway's most consciously avant-garde work. Though the novel is ostensibly about the struggles of Harry Morgan, a charter boat fisherman in Key West during the Depression who finds himself having to smuggle human cargo into the United States to support his family, Hemingway offers a panoramic view of Key West society at the time and writes in the first person for many characters, giving the work an immediacy and power that merits reevaluation. The novel also calls to mind Roland Barthes' "Death of the Author" in certain scenes that seem to question the notion of fundamental knowledge by an author of his intended work, and as such I work to situate the novel in a postmodern context while still exploring the blurrings of race and gender in the novel. In the words of Lutz, "aesthetic concerns... are sometimes denied in favor of social commitments, and social commitments are sometimes denied in favor of aesthetic concerns, but, when pushed, most writers and readers... can honestly articulate both" (12). I argue that Hemingway does honestly articulate both, especially in this, his only novel set in the United States, in a place where the author himself lived, its economy suffering greatly due to the lingering effects of the Great Depression.

Throughout Hemingway's oeuvre, there is always a concern with race and gender. A heavily edited final novel, The Garden of Eden, now seem to belie the mythos of Ernest Hemingway. No longer is he just the hunter, boxer, and heavy drinking "man's 
man." We now see that he was extremely interested in androgyny and blurring the lines between the sexes. My third chapter will posit that this blurring, this looking into the inbetween of things, and not working in absolutes, is something that appears throughout Hemingway's work from the beginning, and that Garden of Eden gives critics the easiest foothold into an analysis of Hemingway as a transgressive author. Furthermore, The Garden of Eden is unique in Hemingway's oeuvre because it explicitly deals with boundaries and social dictates of gender. The novel is Hemingway's most incisive, and the author seems to be questioning his own ideology reflected in the work in the same way that critics like Toni Morrison have.

In Transgressions, Julian Wolfreys attempts to define what a transgressive work is in general and what transgression is in particular. Wolfreys offers the reader what many theorists have not: a clear definition of transgression. Despite how problematic defining transgression may seem to be, Wolfreys makes a compelling case for most theorists to use his schema:

Transgression is, therefore: the act of breaking a law, committing a crime or sin, or doing something illegal, or otherwise acting in some manner proscribed by the various forms or institutions of Law in societies, whether secular or religious, all of which have histories and which themselves are mutable, self-translating. To cross a line, to step across some boundary or move beyond convention - this is what it means, to transgress. (3) 
According to this definition, it is obvious that my project is invested in Hemingway's aesthetic depictions of transgression. It is clear that Bugs transgresses Nick's socially proscribed notions of the agency of black men (in the society that Nick lived in, most blacks would never have the type of freedom and power over a white man that Bugs had over Ad Francis), and Harry Morgan is a clear-cut case of transgression against the Law (this becomes more interesting because he transgresses in order to physically survive and provide for his family). Catherine Bourne transgresses gender boundaries in order to attain happiness. In claiming that Hemingway's work is transgressive, I hope to open further inquiry into his entire oeuvre, and to make it clear that Hemingway's experimental works were heavily invested in dissecting societal bias against women and non-whites. By creating minority characters that struggle under the weight of societal oppression and giving the reader a front-row seat to the injustice these characters face, something heretofore hidden in Hemingway's consciously simple writing style, I hope to create a new way of looking at the author and his work, one that surpasses the common view of Hemingway's texts as the limited and limiting words of a misogynist, racist figurehead of canonical literature. In Hemingway's most famous work, The Sun Also Rises, there is a moment when protagonist Jake Morgan's friend Bill is telling Jake about the travails of a black prizefighter in Vienna who was cheated by his promoter: "Not so good, Jake. Injustice everywhere" (Sun Also Rises 77). One of the major goals of this thesis is to prove that aesthetic considerations of Hemingway's oeuvre will reveal an author deeply invested in deconstructing limiting social discourse and fallacies of racism and sexism. 


\section{CHAPTER I: In Our Time (1925)}

In this chapter, I will be focusing on "The Battler." This story is unique in Hemingway's oeuvre because a black character is imbued with a multiplicity of voices, and there are no easy answers as to why this is the case. Toni Morrison wrote extensively about "The Battler" and used it as evidence of Hemingway's flawed appropriation of black identity. I see this story differently. The character of Bugs is clearly meant to be seen in a positive light because of these complexities. I intend to look at Bugs' relationship with Ad in terms of Hegel's Master-Slave Dialectic and to look at Bugs' actions in the framework of the performativity of identity offered by Judith Butler. Both theoretical stances encourage a positive reevaluation of Hemingway's treatment of race. More specifically, applying these theoretical stances reveal an author that was invested in enacting and then deconstructing binaries of race and gender. As my thesis is concerned with Hemingway's aesthetics, I will also dissect Hemingway's use of space in "The Battler." A love of the work of French Post-Impressionist painter Paul Cézanne compelled Hemingway to apply painterly techniques like the gradual dissolution of the horizon to literature. Cézanne's blurred horizons leading to visually unknowable areas becomes, in Hemingway's fiction, simple settings (like a campfire in the woods in "The Battler") that are both physically separated from society by their distance, but also free from social dictates because of this distance, allowing the author a space to analyze the fallacies of racial and sexual binaries.

"The Battler" is a rather incongruous addition to the Hemingway's first collection of stories, In Our Time. In this story, which is fundamentally about the education of Nick 
Adams (as several stories in the collection are), Nick stumbles upon a white man and his black "pal" Bugs in a campsite far away from society's influence. Nick meets the white, former boxer Ad Francis first, and quickly realizes that the man is mentally unstable and possibly dangerous. He then meets Bugs, who seems to be everything Ad Francis is not: polite, logical, and non-threatening. Bugs eventually has to knock out Ad Francis with a blackjack when Ad gets too belligerent towards Nick, and then sends Nick on his way with a meal for his journey. "The Battler" is a study in the constructedness of race and a breaking down of power dynamics between blacks and whites during a time in America when racial identity still had negative legal implications, such as Jim Crow. Bugs' mannerisms and politeness toward Nick, though exaggerated to an almost absurd degree, serve to critique binary notions that plague race relations: namely, notions that whites and blacks each act a certain way, with blacks always occupying the lesser side of the binary.

Amy L. Strong wrote the most exhaustive and recent text on Hemingway's aesthetic depictions of race, entitled Race and Identity in Hemingway's Fiction. However, Strong's view on Hemingway's use of race proves to be as limited and limiting as the view of critics like Morrison, despite attempting to break free of the common stereotype of Hemingway as a limited author using minorities to limited ends. Strong declares that race in Ernest Hemingway's "The Battler" is confined to "the metaphor of whiteness as a symbol of institutional power," (51) and thus that both the white character Ad and the black character Bugs come full circle in the power dynamics of their relationship because of an inherent whiteness seen even in the pink of Bugs' palm near the end of the story. Moreover, Strong tries to make the case that Hemingway's insertion of certain adjectives 
like "white" to describe Ad's face, especially when he confronts Nick (and thus asserts his power that is both physical and social as a white man), belie the notion that, for Hemingway, all power lies in some inherent whiteness, or that power should be understood in terms of race. This interpretation is extremely troubling, because in focusing on whiteness as a marker of power, Strong seems to be reinscribing a political system that maligns difference, be it psychological or racial, and encourages binary logic. Strong fails to account for Bugs' mannerisms and what they say about race/power relations, and in doing so makes a sweeping generalization about Hemingway's view of race that is confining at best.

To her credit, Strong does gesture towards the problematic nature of a black character that consciously acts in stereotypically white ways: "Nick recognizes him as a 'Negro' without even seeing him, just from hearing his voice and watching the way he walks... these two qualities, voice and gait, are perhaps the two most performable aspects of one's identity" (49). In other words, Bugs is conscious of his decision later on in the story to act in a way that is usually socially prescribed to white "gentlemen". This conscious acting is completely at odds with the biological essentialism that Nick exhibits when first seeing Bugs. Bugs' actions are troubling to readers and critics alike. Strong summarizes the cognitive dissonance experienced by readers:

Bugs' voice reflects a conflicting set of possibilities. Unlike Ad, who speaks in slang-filled phrases...Bugs oozes politeness and refined gentility at every turn... But whether this stance of Bugs' reflects a deferent servitude or a conscious adoption of high-minded gentility remains 
unclear, and in fact his manner seems to encapsulate both. It is precisely the tenuousness of such racially charged categories that Hemingway explores in this story. (Strong 49-50)

Strong seems to want to give credit to Hemingway for exploring the constructed nature of racial categories, but does not explicitly go that far. She is right in highlighting the problematic nature of a black character mimicking white gentility, but is not willing to go further in her analysis. For example, the fact that Ad speaks in slang, such as when he calls Nick "a hot sketch," (Complete Stories 101) meaning a card or a cut-up, is something that is usually attributed to non-whites or marginalized whites. This is further proof of the role reversal in Ad and Bugs' relationship, because Bugs is always proper, and does not use slang at all in the story is further ammunition against racial constructs. Strong also seems to ignore comments made by Bugs that confirm his "conscious adoption of high-minded gentility": "I like to be with him and I like seeing the country and I don't have to commit no larceny to do it. I like living like a gentleman" (Complete Stories 103). However, Bugs' statement is problematic: there is nothing genteel about the way he and Ad Francis actually live if their lives are analyzed in terms of a more urban white gentility. Perhaps Bugs views living like a gentleman as living without being oppressed on the basis of race. Or perhaps Bugs views living like a gentleman as crafting an identity despite the fact that societal oppression exists for him, symbolized in Ad's (white) formerly domineering character. Even so, the idea of a stable identity is constantly challenged throughout the story, and this is something that should be applauded rather than puzzled over. 
Depictions of race in "The Battler" are troubling. Nick knows that the man approaching the small camp is black "from the way that he walked" (100) and also from his voice. However, Bugs' words are at odds with what a superficial, racist view of a black man would allow. He feeds Nick, saves him from the angry onslaught of Ad Francis, and even gives him food for the road. Still, the depiction of Bugs is not completely positive. Bugs admits that he was in jail "for cuttin' a man" (103). This negative aspect of the character should not be seen as repeating a racial stereotype, but should rather be seen as an attempt to craft a clear picture of a character that has both good and bad characteristics. While it is taken for granted that Ad Francis has both good and bad characteristics (presumably because he is white), the fact that a black character can inhabit more than one socially-prescribed role is a credit to Hemingway, who is more often than not accused of marginalizing ethnic minorities and leaving them without a voice, a critique common to many High Modernist authors. ${ }^{1}$

It is telling that neither the brakeman who punches Nick off of the train he stowed away on at the beginning of the story nor Ad Francis are described in terms of race, but as soon as Bugs enters the picture he is identified by Nick as a Negro. Immediately, there is an Other inserted into the scene. The fact that Nick recognizes Bugs as a black man by the timbre of voice and stride implies that Nick has internalized the idea that there is something fundamental and singular in the way that black people walk and talk that

\footnotetext{
${ }^{1}$ Toni Morrison is perhaps the foremost recent example of a critic pointing out the supposedly limited use of minorities in Hemingway. Amy Strong, as I have revealed earlier in this chapter, still sees a limited ideology linking whiteness to masculinity and power in Hemingway's fiction. John Raeburn's "Skirting the Hemingway Legend" offers a good overview of the reasons why Hemingway fell into disrepute among scholars and traces the eventual reemergence of scholarship of the author. Brian Hochman's "Ellison's Hemingways" reveals the ways in which Hemingway impacted Ralph Ellison's writing technique, but also chronicles Ellison's distaste for Hemingway's treatment of racial minorities: "On the social level [Hemingway's] writing performs a function similar to that of the stereotype." (qtd in Hochman).
} 
makes them different from everyone else. In other words, Nick seems to be adhering to biological essentialism. However, Bugs problematizes this notion by using language like a (white) gentleman and acting in certain ways that simply would not fit in with an essentialist view of blacks. For example, Bugs is almost exaggeratedly polite to Nick. While Ad Francis refers to Nick by his first name, Bugs refers to him as "Mister Adams" several times: "Will you cut some bread out of that bag, Mister Adams? ...Hang onto your knife, Mister Adams... Will you bring me the bread, Mister Adams?" (100). In the space of eight sentences, Bugs refers to Nick in a gentlemanly manner three times. This conscious repetition highlights Ad Francis' equivocated and uncalled for familiarity with Nick and makes Bugs' politeness stand out even more. While other texts about the black experience, such as Richard Wright's Black Boy, emphasize the fact that a black man could not address an adult white male by his first name, the actions that Bugs takes, especially knocking Ad unconscious, belie his seemingly servile nature and emphasize something more, namely signifying the agency of a black man in a time when blacks were politically and socially maligned and repressed. Even though Bugs addresses Ad politely with a "Mister" in front of his name, he does not show obeisance. When Ad ignores Bugs because of his steadily rising and incomprehensible rage toward Nick, Bugs says "I spoke to you, Mister Francis" (101). The tone is both chiding and polite: a perfect example of riding the line between how society thought blacks should act and an assertion of agency.

Futhermore, when Ad asks Nick if he's hungry, Nick replies in the affirmative and Ad asks Bugs if he heard that, implying that he should cook for Nick. This seems to 
be a moment of a white man imposing his will on a black man, but Bugs' reply of "I hear most of what goes on" (100) ironically undercuts Ad's power. Bugs goes further toward undercutting Ad's power when he tells Nick later that "He [Ad] likes to think I'm crazy and I don't mind" (103).

A precedent is established early on in the story that Nick understands people by their actions: "That lousy crut of a brakeman. He would get him some day. He would know him again. That was a fine way to act" (97). The use of the word "know" is important because it seems to anticipate Judith Butler's ideas about identity through repetition of actions: Nick will know the brakeman again, specifically through the repeated action of boarding the train. Also, he judges that the way the brakeman acts is obviously rude and dangerous, leading to a heightened awareness of actions from the very first lines of the story. The implication of performance as indicative of an identity is furthered in Nick's first words with Ad Francis:

"I'll get him."

"You're a tough one, aren't you?"

"No," Nick answered.

"All you kids are tough."

"You got to be tough," Nick said.

"That's what I said" (98). 
In this case, to be tough is perceived by Ad Francis as acting in a violent way towards others. However, Nick denies his toughness with his very next words. This calls to mind Judith Butler's notion of identity as a set of repeated actions, and not innate to a person. Interestingly, a concern with acting tough much like the one quoted above is seen on the first few pages of To Have and Have Not, which will be discussed in chapter two.

Bugs' contradictory actions in the story, despite the various speech roles he performs, undoubtedly leave the reader with a positive view of his character. This is true despite the fact that even Bugs' name was probably meant to be unpleasant. According to Amy L. Strong, the original title of "The Battler" was "The Great Man" (45). The alternate title hints at all the complexities and irony within the story: Ad Francis was formerly a great man inasmuch as he was a respected boxer, but he fell from grace and is nothing but a shell of his former self, and at worst he is an unstable misanthrope unfit for white society (he was in jail for beating up scores of people at the drop of a dime). While Ad is nice to Nick at first, he quickly becomes a threat. The danger posed by Ad Francis is juxtaposed with the calm, nonthreatening collectedness of Bugs, who saves Nick's life for no other reason than the fact that he could. The reader has no reason to doubt the fact that this former professional boxer could have killed Nick easily. The use of irony in Hemingway is something critic Toni D. Knott finds extremely important to understanding the author's work. She states that Hemingway

Rel[ies] heavily on irony--a tool that he used often and well- $[$ to] deliberately blur racial lines drawn by humans in order that we might see 
for ourselves the confusion and misunderstanding too often engendered by appearance-based judgments. (87)

Appearance-based judgments abound in "The Battler." Ad Francis owns up to his own shortcomings almost immediately after meeting Nick when he says, "I'm not quite right.... I'm crazy" (Complete Stories 99). However, in the case of Ad Francis, his fractured psyche is mirrored in his equally fractured face: “...his face was misshapen. His nose was sunken, his eyes were slits, he had queer-shaped lips... the man's face was queerly formed and mutilated" (99). Interestingly, Ad tries to put Bugs in the same situation: "This is my pal Bugs... He's crazy, too" (100). This can be seen as an assertion of power by Ad, who as a white man can negatively label others within a Western system of thought replete with limiting binaries. Bugs does not fight Ad's assertion, but there is a significant undertone of resistance to Bugs' conversations with Ad.

Critic Nicholas Gerogianis does not see Bugs as having any agency, merely miming socially prescribed roles of submission and servility:

And Bugs is his caretaker, going into town and brining food back to Ad in the woods. He watches over Ad like an old woman watching over a pot of boiling soup, treating him gently, sensitively controlling and timing the things that stimulate him, and when he boils over relieving his pressure with the blackjack. (Gerogianis 183).

It is intensely troubling that Gerogianis uses language like "woman watching over a pot of boiling soup," and the adjective "sensitively" in reference to Bugs' actions. The critic 
seems to have internalized limited gender roles and uses this problematic framework to try and prove Bugs' subservience. It seems that, for the critic, a woman is defined by her "nature" as a domestic creature. This outdated and rather Victorian view of the female sex applied to Bugs does the story a great disservice because it ignores the transgressive quality of Bugs' power in his relationship with Ad.

Furthermore, the critic, eager to paint Bugs in a subservient light despite Ad's physical and psychological dependence on him, ignores the loaded theoretical landscape presented by the camp site. Nick is knocked off a train, a sign of the power of industry in capitalistic society, and is inserted into a space where a white, capitalist, Western and metaphysical society is not present by virtue of the camp site's isolation: "It was dark and he was a long way off from anywhere" (Complete Stories 97). Critic Ron Berman argued that Hemingway was greatly influenced by the landscapes of Paul Cezanne, and tried in his writing to mirror the Post-Impressionist's work. Berman contends that in "The Battler,"

We move from perspective to a point beyond viewing, and from technique to meaning - we now know the tendency of the story, from known to unknown. It is characteristic in Hemingway to begin on a straight road or roadway, then to experience an entirely different kind of locus of movement—and also of the mind. (148-9)

In other words, Hemingway was consciously channeling the idea of unknowability reflected in Cezanne's work by making his characters enter unfamiliar landscapes signaling shifts in mood, thought, and boundaries, be they societal or psychological. By 
channeling those vague horizons and roads that lead to places a viewer of art hung on a wall will never know, Hemingway was allowing himself the opportunity to analyze and deconstruct boundaries as boundaries.

The isolated setting of "The Battler" and the above example of Bugs undercutting the commands of Ad seem to suggest a conscious literary depiction of the later stage of Hegel's Master-Slave Dialectic. At one point, Ad could have been what Hegel terms "the lord" and Bugs "the bondsman," but at this point in their relationship, it is clear that $\mathrm{Ad}$ is much more dependent on Bugs than Bugs is on Ad. While Ad does have the money to keep them alive (though he gets it from an ex-wife, an issue that is interesting because of the reversal of gender roles and will be analyzed shortly) it is Bugs who is essential to Ad and not the other way around. Hegel states that, "Through this rediscovery of himself by himself, the bondsman realizes that it is precisely in his work wherein he seemed to have only an alienated existence that he acquires a mind of his own" (Hegel 635). In other words, in a Master-Slave or Lord/Bondsman relationship, the lord comes to depend on the bondsman, who in turn finds his identity in the labor that the lord depends on him for. Thus bringing food to Ad is not a feminine activity, but the assertion of Bugs' own position of power within his formerly oppressive relationship with Ad. Interestingly, Hegel asserts that the fear of death is integral to keeping the lord/bondsman relationship alive. However, it is clear that Bugs does not fear death from his "lord," not only because he finds his identity in the work he does but also because of the physical presence of a blackjack to defend himself with. This can perhaps be seen as a break from the MasterSlave Dialectic and even more evidence of the assertive qualities inherent in Bugs, and of 
unwillingness in Hemingway to depict a stereotypical and racist power dynamic.

Furthermore, the blackjack is a fairly obvious phallic symbol emphasizing Bugs male authority.

Judith Butler addresses the performative aspect of identity and the non-existence of a true, stable identity in much of her work. Her theories enable a better understanding of the character of Bugs. In her essay "Performative Acts and Gender Constitution: An Essay in Phenomenology and Feminist Theory," Butler states that "through language, gesture, and all manner of symbolic social signs" ("Performative Acts" 270) a subject constructs his or her social reality and identity. What is important here is the assertion that identity is part of an act, something shaped by a bevy of societal dictates and not based on anything essentially masculine or feminine. The fact that Ad Francis' wife is financially stable enough to send her husband (whom society dictates be the provider in a nuclear family) money while he camps out in secluded areas with another man (and the hint of homosexuality in Bugs and Ad Francis' relationship has been argued compellingly by George Monteiro) is evidence of an author who is consciously crafting an extremely non-heteronormative, non-socionormative space to confront the reader.

Though Butler focuses on gender in her analysis of performativity, her ideas can be tied to race as well due to the shared history of oppression based on gender and race in Western and metaphysical discourse. Butler further clarifies her position, stating that "I will understand constituting acts not only as constituting the identity of the actor, but as constituting that identity as a compelling illusion, an object of belief" (271). It is important for the purposes of this paper that the belief in identity and gender difference is 
compelled "by social sanction and taboo" (271). By placing these characters in the neutral secluded camp site, Hemingway frees himself to examine the influence of societal roles on the performance of identity without having to explicitly describe society's influence, instead having the characters bring society's influence into this place, for example Nick's ease in creating an Other when Bugs walks into the camp site.

For his part, Bugs' object of belief is that it is good to be a gentleman. However, he is only able to do this in a space that is outside of the society that holds blacks as inferior and would ostracize them or threaten death. Through his relationship with Ad, Bugs shows his agency as a self-conscious being, despite the fact that racial taboos still dominate the larger societal landscape. Bugs' repetition of linguistic norms and a general politeness usually attributed to white gentlemen becomes, then, his preferred method of attaining freedom inasmuch as it allows him to skirt the system that would oppress him.

There is no simple answer to the question of Bugs' identity, and a theorist like Butler would not even consider identity as something materially real. However, Hemingway proves to have been conscious of the problematic nature of race relations, racial stereotypes, and how society impacts the performative aspects of one's identity from the onset of his literary career. This is a far cry from the Hemingway that has been painted as an incorrigible racist by many critics.

Though my focus for this chapter was "The Battler," I chose to offer a brief analysis of "Cat in the Rain," another story from In Our Time, as evidence that a reading focused on Hemingway's aesthetics is fruitful because it reveals an author who was not committed to reinscribing limiting societal rules for women and minorities, but instead 
offering the reader a front-row seat to the injustice that binary logic and rigid societal mores already have built into them. "Cat in the Rain," is replete with transgressive gender roles. It is a study in the constructedness of societal mores. Some critics see the story as strictly autobiographical: Critic Peter Griffin asserts that many critics have seen "Cat in the Rain" as autobiographical, and goes on to assert that the story is no more than a "Dirty Joke," a riff on the idea of "wet pussy," reflecting the inability of Hemingway's second wife Hadley to conceive children. Though there might be some biographical basis for these interpretations, the story proves to be another instance of Hemingway's constant need to poke and prod at societal constructs. It is also, according to Carlos Baker, a story that "presents a corner of the female world in which the male is only tangentially involved" (90). That corner is the experience of a woman trapped in an unhappy marriage. Not unlike the presence of Bugs in "The Battler" serves to undermine readers' expectations about how black characters behave, Hemingway's use of the wife in "Cat in the Rain" seems to force his readers to consider the position and plight of female characters, something that he simply is not known to do.

As the story begins, we are told that "There were only two Americans stopping at the hotel. They did not know any of the people they passed on the stairs to their way to and from the room" (Complete Stories 129). This is similar to Nick's position in "The Battler" because the characters are away from the known in their lives, namely, American culture and society. They are in a space where they are unknown, uncomfortable, and out of their element, just as Nick was. Though the surroundings of the hotel are painted in vivid, typical Hemingwayesque detail, from the "big palms and green benches in the 
public garden" to the "bright colors of the hotels facing the gardens and the sea" (129), the room the couple is in is always described in generic nouns - the woman is looking out of a "window," the man is at a "bed." Like the simple campfire in "The Battler," the hotel room becomes a space isolated from society which gives ample room for the author to dissect intimate and complicated issues of gender.

The wife in this story seems to be sexually dominant and favoring subservient men, as seen in her view of the hotel owner: "She liked the way he wanted to serve her" (130). This is definitely different from the typical view of man as dominant and woman as submissive, and will be echoed much later in the relationship between David and Catherine Bourne in The Garden of Eden. The relationship depicted in this story is problematic, however, because the man seems to have all the power, in terms of dictating the female's actions. The brief line about how the woman liked the hotel owner's obsequious servility (a manner of being that hotel owners are ostensibly paid to enact, but still something she does not get in her own relationship) is a clear indicator of the woman's needs not being fulfilled in this relationship.

However, in this particular instance, the female does not relish the switch in gender roles as much, especially her hairstyle, which becomes paramount in The Garden of Eden, but here seems forced upon her by her male counterpart:

"Don't you think it would be a good idea if I let my hair grow out?" she asked, looking at her profile again

George looked up and saw the back of her neck, clipped close like a boy's. 
"I like it the way it is."

"I get so tired of it," she said. "I get so tired of looking like a boy."

"You look pretty darn nice," he said. (131)

The woman here seems to be helpless to the whims of the man. She cannot cut her own hair of her own free will, but instead is only able to question her partner's view on the subject, never assert her own wants or needs in relation to her own body (she can, however, assert her desire for the cat, something that is of no relation to their actual relationship and a classic example of displacement). Still, the fact that she so clearly enjoys men serving her undercuts her seemingly submissive nature. The fact that her husband likes that she looks like a boy is interesting as well in that it suggests a nonheteronormativity. It could also be read as a homosexual man in a loveless and childless relationship. Why would the man be in this relationship where he does not even want to father a child? The cat of the story is fairly convincing as a metaphor for a child. Thus there is compelling evidence for a queer reading of this story. More generally, however, "Cat in the Rain," like "The Battler," seems to be committed to going against what would be considered "normal" societal roles is yet further proof of Hemingway's own investment in deconstructing social and sexual boundaries and implies that Hemingway was interested in questioning heteronormativity, which is the goal of modern Queer readings. It is telling that, at the end of the story, the woman gets the cat she wanted and that "Of course the hotel keeper had sent [the attendant with the cat]" (130). The story ends with the man performing a submissive act to a woman and not the other way around. 
The transgressive and theoretically complex nature of the In Our Time stories does not end with the ones I have analyzed above. As I briefly mentioned, almost every story in the collection can be analyzed in this fashion, both for aesthetic choices and for the complex issues of race and gender that those aesthetic decisions depict. This is a far cry from the Hemingway that most critics have maligned, and what is truly astounding about these stories are that they are the first ones that the author published with success. Hemingway's investment in dissecting societal roles and rules would only continue on, not only in his most famous works like The Sun Also Rises and For Whom the Bell Tolls, but also in his most experimental and sometimes critically maligned works. 


\section{CHAPTER II: To Have and Have Not (1937)}

My first chapter focused on Hemingway's dissection of race. The problematic nature of race was still a subject that remained very much alive in the author's mind, as evidenced by To Have and Have Not. This novel is not one of Hemingway's most critically adored. Robert E. Jungman quotes Susan Beegel's assertion that "too many critics are [still] satisfied with simply repeating negative remarks about To Have and Have Not's jerry-built structure" (224). However, I believe that this novel is more mature and forceful in its treatment of race specifically because of its aesthetic structure.

Throughout the novel, we see one character learn, through having violence inflicted upon him, that violence inflicted upon others, whether it be verbal (such as calling a black man a "nigger," as many Hemingway characters do) or physical, is unnecessary and unjust. The treatment of race in this novel, then, is more straightforward—Nick does not hurl racial epithets at Bugs, but protagonist Harry Morgan, his wife, and some other characters do use racial epithets. Moreover, violence against minorities is also depicted in this novel. Hemingway seems to be aware of the problem of racism and this work forces his readers to see a character who wholly subscribes to a racist ideology, and then see why this character's view changes. In this way, To Have and Have Not is, like "The Battler," about education - Nick is educated that blacks do not essentially act or think one way, and Harry Morgan, the protagonist of this novel, is educated about the destructive nature of divisive rhetoric and ideology. My reading of Hemingway reveals that though he is an author who has been almost universally regarded as the embodiment of his misogynistic, racist characters, Hemingway was actually trying to probe the fallacies of racism and in this case, attempt to reform the protagonist in a way that is more forceful than the lessons 
imparted to Nick. My reading of To Have and Have Not will include theorist Jean-Luc Nancy's ideas about the nature of community and the divisiveness of concepts of race and gender. Nancy held that all meaning is relational and determined by the fact that all people are singular, but live inside a world with billions of other singularities, and thus all meaning is derived from one's experience with another singularity. Meaning is not derived from ideas of absolute meanings which can lead to the racist ideology of Harry Morgan. My reading will also include a Derridean deconstruction of metaphysics as it relates to some of the characters in the novel. Furthermore, it is important to focus on protagonist Harry Morgan's subscribing to a fundamentally flawed world view that disregards minorities and, in so doing, makes Morgan prone to the violence that ends up causing his death. Harry Morgan's death and his anticipation of Nancy's theory has a transgressive quality to it, as do Hemingway's aesthetic decisions throughout the novel.

The first words of the novel set the tone for what is arguably Hemingway's most avant-garde work: "You know how it is there early in the morning in Havana with the bums still asleep against the walls of the buildings; before even the ice wagons come by with ice for the bars?" (To Have 3). The tone is disarming because of its intimacy. This is one of the only texts where Hemingway's third-person omniscient narrator is replaced by a first-person narrator. Most of Hemingway's works start in the third person limited, that is, a narrator that is omniscient but is limited to the thoughts of one character in the text, such as in "The Battler," where the reader is privy to some of Nick's thoughts, such as “That lousy crut of a brakeman" (Complete Stories 97). Hemingway usually uses a third person limited narrator to establish who the characters are or where they are and further 
flesh out the story from that point of view. The fact that this story addresses the reader gives it a sort of readerly dissonance, because not many readers living in the United States would actually know what Cuba was like at the time. It is a bit ironic to assume the reader knows what an empty square looks like at five o'clock in the morning in Cuba. This acknowledgement of the reader draws attention to the fact that one is reading in order to enter a different environment, not because they already intimately know the locales described within.

Furthermore, the idea of "acting tough" that Ad Francis talks about in relation to young people in "The Battler" is also evident in the beginning of this novel. The reader sees that Harry Morgan goes into a café to be propositioned by three Cuban men who want to be smuggled off the island. When Harry says that he cannot take them because he "d[oesn't] carry anything to the States that can talk," (To Have 4) the meaning is lost in translation and the men think Harry believes them to be untrustworthy. This leads to some harsh language, and then Harry says "don't be tough with me" (4). Harry continues: "Don't be so tough so early in the morning... I haven't even had my coffee yet" (5). One could understand why a man desperate to be smuggled off of an island would be highstrung, but this idea of toughness ties back to Judith Butler's ideas about identity being formulated by repetitive actions. In this case, the man says "tough" things several times, to the point where Harry argues that it is too early in the morning to be tough, implying that the toughness is a tool or a mask that the man is using, not something genuine or innate in his identity.

In Being Singular Plural, Nancy claims that 
There is no meaning if meaning is not shared, and not because there would be an ultimate or first signification that all beings have in common, but because meaning itself is the sharing of Being. Meaning begins where presence is not pure presence but where presence comes apart in order to be itself as such. (2)

In other words, racist ideologies believe implicitly in pure presences, so destroying the Other who is impure makes "sense," and there is a particular kind of meaning in destroying other people: namely, preserving your culture's bloodline (which is perceived as better than other bloodlines). However, in negating (either psychologically or physically, through violence) Otherness, you are robbing yourself of meaning, because, as Nancy sees it, all meaning and the nature of Being itself is relational:

A single being is a contradiction in terms. Such a being, which would be its own foundation, origin, and intimacy, would be incapable of Being, in every since that this expression can have here. "Being" is neither a state nor a quality, but rather the action according to which can't calls "the positioning of a thing." (Being Singular Plural 12)

In other words, a being knows itself through interactions with its environment and other beings in that environment. A being comes to learn about itself through its experiences with other beings. To state that there is a single being is to assert that a being exists that was brought to fruition without having had the formative experience of interacting with other identities. The positioning of a being is key: virtually all human beings in the world are brought up in close proximity to other beings, and this positioning ensures a healthy 
development of identity. To believe in racist ideologies is to believe in a single, limited and limiting ideology that does not take into account the importance of multiple identities to the nature of Being, and thus to kill others would be to ensure living in stagnation, where nothing means because you do not have a connection to an Other, merely many identities who share the same beliefs.

Harry, a charter boat fisherman, has a black hand on his boat who helps him bait the fishes for clients. However, Harry's view of the man is extremely troubling: "He's a real black nigger, smart and gloomy, with blue voodoo beads around his neck under his shirt and an old straw hat" (To Have 11). The man never gets a name and is always looked down upon by Harry. The third-person narrator in this novel seems to shift with the viewpoints of the characters, and so racist statements show up only when Harry is being mentioned: "The man, whose name was Harry Morgan, said nothing then because he liked the nigger and there was nothing to do now but hit him, and he couldn't hit him. The nigger kept on talking" (69). This passage is a good summary of Harry's view throughout most of the novel: even if he feels some good will towards the black man, whose name the narrator tells us is Wesley (the third-person narrator is a problematic figure, who can name for the sake of clarity, it seems, but is also bogged down by the viewpoints of the characters), Harry cannot at this moment break free from the system of thought that holds that Wesley, because he is black and Harry is white, is a lesser being.

Harry has internalized the sort of racist rhetoric that Jean-Luc Nancy fights against in Eulogy for the Melee and that many critics have accused Hemingway of propagating in his stories through the limited role and voice of minority characters. Harry 
was obviously racist from the very beginning of the novel. Harry refers to all black people in the text as "niggers" and does not give them a voice. Toni Morrison has analyzed the troubling voicelessness of minority figures in To Have and Have Not and has come to the conclusion that white authors use Africanism to fulfill certain roles in their writing, no matter how incorrect the author's views might be. While I do not agree entirely with Morrison's conclusions, I feel it is important to acknowledge and analyze Harry's racism, as it makes his last words and the implicit renunciation of racism even more powerful and suggests that Hemingway the author was consistently committed to exposing problematic issues of race and gender in his fiction.

Harry is murdered three-fourths into the novel in retaliation for murdering a human trafficker he had done business with. He is shot aboard his boat, but lives long enough to impart his last words upon two members of the Coast Guard who eventually find his boat drifting at sea:

'A man,' Harry Morgan said, looking at them both. 'One man alone ain't got. No man alone now.” He stopped. 'No matter how a man alone ain’t got no bloody fucking chance.' It had taken him a long time to get it out and it had taken him all of his life to learn it." (225)

I take this passage as relating to Jean-Luc Nancy's theory of singular plurality: “Being singular plural means the essence of Being is only as coessence" (Nancy 30). In other words, Nancy proclaims that inasmuch as there is meaning in the world, it cannot be found or thought of in ways typical to Western, metaphysical thought, but that the meaning of being is relational: we are singular beings united by the fact that there are 
billions of singularities. I posit that Harry's statement anticipates Jean-Luc Nancy's theories about community, and that Harry Morgan's entire life as we see it in the novel is a powerful literary depiction of someone coming to terms with the inefficacy and injustice of the close-minded, binary-riddled Western metaphysical thought. Instead of reaffirming the closed-minded thinking of Harry Morgan, who is definitely one of Hemingway's most racist characters, Hemingway makes Harry see the error of his ways, and attempts to transfer this message of reform to the reader.

The fact that Harry asserts that no man is alone "now" is a bit problematic. It could be commentary on the state of Key West at the time. Hemingway lived in Key West during the Depression, during which Key West was one of the poorest cities per capita in the United States, with "at least eighty percent of its inhabitants on the welfare rolls" (Boulard 166). Harry's financial instability led him to human trafficking and murder. Harry kills the mediator who wants the immigrants smuggled in for no good reason other than he can, possibly to wipe his hands of the whole matter and not have it traced back to him or his family. By saying that no man is alone now, Harry could be reflecting on the violence that poverty and class systems sometimes make possible. Factors like money and race and gender have a way of alienating people from each other. To Have and Have Not is Hemingway's most definitive text against limiting societal mores, forcefully emphasizing unity in the face of these limiting social forces.

In asserting that no man has a chance without other people, Harry seems to be speaking about Nancy's concept of fragmentary demand. Nancy argues that since all meaning is relational, that "meaning is itself the sharing of Being" (2). Nancy further 
elucidates his point when he states that "existence can only be grasped in the paradoxical simultaneity of togetherness (anonymous, confused, and indeed massive) and disseminated singularity (these or those 'people[s].' or 'a guy,' 'a girl,' or 'a kid')" (7). Furthermore, being with other people and deriving meaning from the fact that we rely on other people implies that people have an as yet unspoken responsibility towards each other, an ontological demand based on our shared worldly experience (an experience that has been previously discussed in this chapter). The fact that it took Harry all his life to learn these lessons is not tragic, but positive, because Nancy's theories of community are virtually impossible to implement on a "tangible," nation-wide political level, but are far more effective in the mind of one person, who can pass it to others.

Stylistically, To Have and Have Not is one of Hemingway's most experimental works. In writing a novel about many different characters and allowing some of them to have first-person, stream of consciousness accounts of their experience, Hemingway seems to be invested in the idea that "being-with-one-another" (3) is what gives a sort of meaning to Being. In The Fragmentary Demand: An Introduction to the Philosophy of Jean-Luc Nancy, Ian James states that "Nancy unites and reworks Heidegger's thinking of being in the name of a thinking of multiplicity, fragmentation, or what Nancy himself comes to call the singular-plural of being" (7). I posit that Hemingway wrote To Have and Have Not in a consciously fragmented style that anticipates Nancy's theory of singular-plurality.

Chapter twenty-four of the novel, directly after Harry's last words in chapter twenty-three, is a departure from the narrative strategy of the rest of the novel because it 
is told in third-person and is not exclusive to a single character, as it has been for the anteceding chapters of the book. After Harry's death and his message of community, it is telling that Hemingway focuses on the community at the marina in Key West. Nancy's Eulogy for the Melee is helpful in understanding why this seemingly incongruous chapter is included in the novel:

The whole task here, is to do right by identities, but without ceding anything to their frenzy, to their presuming to be substantial identities ("subjects," in this sense). This task is enormous, and it is very simple. It is the task of a culture remaking itself, or the recasting of thinking such that it would not be crude or obscene like every thought of purity. It means mixing together again the various lines, trails and skins, while at the same time describing their hetereogenous trajectories and their webs, both those that are tangled and those that are distinct. It is the task of never believing in the simple, homogenous, present "man." ... it is the task of knowing that the subject of knowledge is now only someone, and like every someone, someone of mixed blood. (Nancy 147)

This particular essay of Nancy's concerns issues of race and mixed blood, which are prevalent in To Have and Have Not, from Harry's above-mentioned racism to the racism of other characters, be they minor or major (There is racist behavior, for example, in chapter twenty-four, as I note below). Chapter twenty-four follows the third-person omniscient narrator in an intimate study of the lives of several people who own boats that are anchored at the marina. The narrator, much like a ghostly presence, seems to fly from 
one boat, know the problems and lives of all the characters, and then leave that particular boat and go into the next one. This happens four times and takes up nineteen pages, making it one of the longest chapters in the book. I contend that this chapter is a fairly straightforward attempt to make the reader aware of what Nancy terms "hetereogenous trajectories and their webs, both those that are tangled and those that are distinct" (147). Again, since Nancy's theory of singular plurality contends that all meaning is relational between many singular entities, he avows that it is important to acknowledge the different connections that hold people together or do not hold them together. That is what this particular chapter does. Even though there are physical boundaries between the characters (i.e. the walls of the boats and the space between the boats), writing about the characters as if there were no differences, as if all their respective problems were on the same plane, is something I find very Nancy-like.

The first person described is a Cuban watchman, "uncomfortable and anxious in his cap, his long mustache and his deshevelled authority," (To Have 227) who is vainly trying to keep people away from the marina and who is subsequently ignored by two yachtsmen: "Hey. You canna comein," (227) the watchman says uncertainly. One of the men immediately gets verbally violent, proclaiming "What the hell. We're off a yacht" (227). Though the only punctuation here is periods, the reader can imagine the entitled frustration in the voice of whichever yachtsman said that (because at this point neither of them are named).

Ostensibly rich, white, and unused to being shut out from their yachts, these yachtsmen serve as an indirect commentary on the issue of race: the two white men 
clearly think they are better than the flustered Cuban guard and step over the boundaries his job has established because they see themselves as above that system. When the watchman with his "disheveled authority" (227) further protests the intrusion of the two men by stating that "nobody supposacomein," (227) the men react with more vitriol. First there is a threat of physical violence when one says "get back," and the other says "don't be stupid" before pushing the watchman aside and continuing on his way. (Though this racial encounter is not exactly violent, I believe we can see the arrogance that can lead to violence against races in the exchange between the three men.)

Once the two men, Henry Carpenter and Wallace Johnson, get to their yacht, they gossip mean-spiritedly about friends, but then they fight amongst themselves. Wallace tells Henry that he "never feel[s] strongly because [he has] no consistency" (229). Wallace seems to believe in what Nancy called "the simple, homogenous, present 'man"" (147). However, Nancy also stated that "In order for the human to be discovered, and in order for the phrase 'human meaning' to acquire some meaning, everything that has ever laid claim to the truth about the nature, essence, or end of 'man' must be undone" (XIXII). It is interesting that almost immediately after Harry Morgan's realization about the nature of meaning and being as coessence, the reader sees one character who thinks the exact opposite. Wallace Johnston thinks in a typically Western notion of meaning as being present and language re-presenting meaning. Wallace believes in fundamental notions like consistency, which would be another word for order or logic. In Wallace Johnston's mind, Henry Carpenter is the maligned second term of the binary, he is inconsistent or chaotic. 
Henry Carpenter is in this case Wallace's counterpoint, who analyzes his friendship to Wallace in terms of what they do for each other: "I go on your bloody yacht, and at least half the time I do what you want to do, and that keeps you from paying blackmail to the bus boys and sailors" (To Have 229). However, the most important line comes later in the conversation, again from Henry. Henry has a sort of existential breakdown and does not know what he is doing with his life anymore. He wants easy answers (the kind offered by Western thought) but he cannot get easy answers at this stage of his life: “The eternal jackpot. I'm playing on a machine now that doesn't give jackpots anymore. Only tonight I just happened to think about it" (231). It seems that Henry has, like Wallace, subscribed to limited, Western metaphysical frames of reference. The slot machine Henry references could be a metaphor for any definite meaning offered in metaphysical thought, any final signifier. However, the metaphor Henry offers seems to undercut teleology. Henry has, for some reason, seen something else other than the Western system of thought, and it leads him to question the being-with his friend and what it means.

Perhaps Henry Carpenter's experiences have led him close to the same realization that Harry Morgan made earlier. The third-person narrator follows the men's discussion with an extremely detailed, page-long history of their lives, careers, and social status. Inserting such details about Wallace as "M.A. Harvard, composer, money from silk mills, unmarried, interdit de sejour in Paris, well known from Algiers to Biskra" (232) and then putting it next to such details about Henry as "M.A. Harvard, money now two hundred a month in trust fund from his mother, formerly four hundred and fifty a month until the 
bank administering the Trust Fund had exchanged one good security for another" (232) forces the reader to acknowledge two separate lives that have meaning by their relation to each other at the moment.

After focusing on Wallace and Henry, the narrator glides above the rest of the people on the marina: "Aboard the other yachts... there were other people with other problems" (233). The reader sees a speculator who gave in to greed so much that he lost his family and lies in bed alone and miserable, wanting to drink but forbidden by his doctor for the sake of his liver. The speculator "did not think in abstractions, but in deals, in sales, in transfers and gifts" (234). The scene then switches to a happy family in the next yacht, who made their money bottling alcohol (which, ironically, causes the addiction that is killing their unhappy neighbor), and then to an illicit affair going on in the next boat. By demonstrating that the people on the other boats have problems, the narrator seems to be gesturing towards a similarity amongst the disparate elements by dint of the fact that they are beings in society with issues that make them unhappy, or happy, as the case may be. Putting the reader in the midst of all these people strongly reinforces Harrry Morgan's last words in the previous chapter and Nancy's claims about the importance of the "with" of being.

Chapter twenty-four also embodies Nancy's idea of what interests people about the arts:

[The arts are] access to the scattered origin in its very scattering, it is the plural touching of the singular origin. Art always has to do with cosmogony, but it exposes cosmogony for what it is: necessarily plural, 
diffracted, discreet, a touch of color or tone, an agile turn of phrase... exactly because it is the birth of a world (and not the construction of a system). A world is always as many worlds as it takes to make a world.

In other words, art is interesting to singular beings because it exposes the plurality of experience while coming from a singular being. Art is an origin story inasmuch as it forces the viewer or reader to account for the varied experiences (or the varied respective worlds) of any artist. By profiling seemingly disparate characters in quick succession, chapter twenty-four of To Have and Have Not cannily forces the reader to acknowledge the many worlds that it takes to make up the one world of the text. In fact, these words describing Wallace and Henry are worlds unto themselves: "M.A. Harvard" brings up a certain world in the readers mind, as does the fact that Wallace is a composer. These descriptors all have separate expectations and relations within them that the reader is assumed to understand. It bears noting that Tom Lutz also asserted something similar to Nancy in relation to the value of the literary. Lutz argued that Theodore Dreiser's and Henry James' personal beliefs did not detract from the "'effect of the real' they achieve, their wit, their affective power, and many other elements of their literary art are enabled by this multiplicity, this openness" (Lutz 13-4). The openness Lutz described is the ability of an author to "do the voices of people across an array of social positions, mimicking the speech of their several microclasses" (13), which is what Hemingway achieves in this chapter as well. 
Harry's social position was nowhere near that of the wealthy yachtsmen discussed above, but his troubling racism is definitely "effect of the real," no matter how distasteful it may be to a modern audience. Furthermore, it is because of Harry's previous racism that his assertion that "a man alone ain't got no bloody fucking chance" is important. Harry's need to communicate the importance of connection to the Other seems to remedy his previous aversion to (specifically racial) Others. The best example of Harry's previous racism (though we see his racism throughout the novel, as indicated above) is related to the reader by his wife Marie after Harry is dead. First, Marie echoes some of Harry's racism, but even more explicitly: "Cubans are bad luck for Conchs. Cubans are bad luck for anybody. They got too many niggers there too" (258). Then, Marie relates an instance of violence Harry perpetrated against a "nigger" during a vacation to Havana that the couple had taken when they were able to afford it: "We were walking in the park and a nigger said something to me and Harry smacked him, and picked up his straw hat that fell off, and sailed it about half a block and a taxi ran over it" (258). Marie can be seen as bearing witness to Harry's actions, but Marie is still mired in a Western metaphysical system that looks down upon Others, making Harry's actions in the tale a point of pride and fond remembrance where they would be troubling to anyone outside a Western system of thought. Marie is therefore unable to come to the same near-death realization that Harry did. Hemingway was a master of irony, and I believe that Harry being remembered as less than he was at his moment of death (because Harry is ostensibly a more functional and less destructive person after having realized the necessity of community and the fallacy of racial prejudice) is unjust, but the fact remains that the reader has seen Harry's revelation and perhaps it will resonate in a way that it did 
not with even the two Coast Guard men, who do not understand Harry's words and assume he is delirious.

The final chapter of the novel is devoted to Marie's remembrances of her husband. As discussed above, most of her memories paint a picture of a violent man who was limited in his connection to others. Marie did not get to hear his final words. Perhaps those words would have changed her view of Harry. However, the reader did hear those words, and they resonate so much that a sort of coda is added to the end of Marie's chapter. A clear paragraph break signals the shift from Marie's stream-of-consciousness to a more detached third-person narrator's perspective. The narrator informs the reader that "Outside it was a lovely, cool, sub-tropical winter day," and that "Some winter people rode by [Marie's] house on bicycles. They were laughing. In the big yard of the house across the street a peacock squawked" (261-2). The book then ends with the narrator pulling back from Key West and describing a yacht coming into the harbor and, interestingly, pulls back even further to tell the reader that at "seven miles out on the horizon you could see a tanker, small and neat in profile against the blue sea, hugging the reef as she made to the westward to keep from wasting fuel against the stream" (262).

Though this coda could be read as an ironic ending that simply tells the reader that life goes on, I believe it is very much related to Nancy's theories. Even during moments when the characters of the novel feel most acutely alone and disconnected from others, the third-person narrator reminds the reader that these people are not disconnected. All people in this novel are connected, be it by physical proximity, such as the bicyclists passing by Marie's house, by the very nature of the tiny community on Key 
West (which is a very small island), or through Nancy's theory of singular plurality. Though the language of the coda personifies the tanker, this is just a familiar maritime tradition to gender boats. It is not important what the boat is doing (because, as we know, the tanker can never be "doing" something of its own accord), but the fact is that there is someone steering the tanker, ensuring that it is finding the right course and maximizing fuel efficiency. Thus the final image the text gives us is of a person piloting a tanker far from the shore of an island community, firmly re-emphasizing that no one is ever alone, even if people are physically near, and once again reminding the reader of the connectedness of all singular plural beings through Hemingway's particular aesthetic decision of breaking the established narrative style of the novel and focusing on many characters at once. 


\section{CHAPTER III: The Garden of Eden (1987)}

For this chapter, my interest is in sexual transgression, which can be seen in The Garden of Eden, but is not without precedent in other Hemingway works. For example, in the In Our Time stories, there is an uncomfortable suggestion of incest in "Soldier's Home" between Krebs and his sister Helen. Helen tells Krebs, who the reader comes to know is greatly affected by his wartime experiences and probably experiencing posttraumatic stress disorder, that she tells her classmates that Krebs is "[her] beau" and then asks “Couldn't you be my beau, Hare, if I was old enough and if you wanted to?" to which Krebs answers "Sure. You're my girl now." (Complete Stories 114). The exchange cannot be read as something that a child imagines in an innocent or naïve way, because Krebs' sister shows a mature knowledge of relationships, recognizing her age would be an issue and her brother's own thoughts on an incestuous relationship could be an issue as well. However, the implication here is that Krebs would be okay with an incestuous relationship, simply because it is easier than being a functioning member of society and talking to others. Earlier in the story, Krebs thinks about the women in his town: "He would like to have one of them. But it was not worth it... he would not go through with all the talking" (113). Perhaps Krebs' sister is the perfect woman for him because he does not have to try. Furthermore, "Mr. and Mrs. Elliot" chronicles the loveless and sexless marriage of a young poet and his older wife, who ends up sleeping in a separate room from her husband with a "girl friend" who "was older... and called her Honey" (125). These stories, along with the possible homosexuality in "The Three-Day Blow" and the previously discussed experimentations with haircuts in "Cat in the Rain" suggest that Hemingway was an author committed to examining sexual transgression in his work. 
Nowhere is this preoccupation with sexual deviancy more evident than in the posthumously published Garden of Eden, a story about a writer, David Bourne, and his wife Catherine, who enjoy switching genders during sexual activity and in everyday situations. The Bournes' complex relationship is further strained when Catherine introduces the beautiful Marita into their marriage as an equal third partner. Catherine becomes consumed with jealousy at the arrangement and eventually burns most of David's manuscripts. The Garden of Eden offers a culmination of my reading of Hemingway, that is, Hemingway as an author consciously subverting (or transgressing) societal mores through his aesthetics. The novel invites reading it through the lens of transgressive theory. To this end, I will apply some of the thought of transgressive theorist George Bataille to the novel. Furthermore, the novel is Hemingway's most postmodern, both because of the socially avant-garde subject matter and because of some of the aesthetic techniques used. I will analyze the scenes that most clearly show this heretofore unexamined dimension of Hemingway's art. Though the novel was not edited by Hemingway, and according to many critics was done a disservice by editor Tom Jenks ${ }^{2}$, there is a meta-awareness of the writing process that is definitely postmodern and, despite an ending where the white, male character is back to writing works that are troublingly unconcerned with the plight of underrepresented or repressed females and characters of other races, the novel still emerges as a testament to the strength and boundary-pushing brought about by what is Hemingway's most complex female character, Catherine Bourne.

\footnotetext{
${ }^{2}$ Chris L. Nesmith neatly summarizes the problematic nature of Jenks' editing in "“The Law of an Ancient God and the Editing of Hemingway's Garden of Eden: The Final Corrected Typescript and Galleys"
} 
In my introduction, I mentioned Julian Wolfreys' definition of transgression to give a clearer picture of what I believe Hemingway is doing by using his aesthetic skill to dissect social mores and dictates. Wolfreys views transgression as the act of crossing a boundary, be it political, social, or otherwise. Wolfreys further complicates his definition of transgression as follows:

To stray from the straight and narrow, to trespass, to overstep a limit - all such definitions share common assumptions, whether explicitly or implicitly. Whether one thinks of breaking civil or moral laws, whether transgression has to do with sexuality or another aspect of accepted behavior, the common assumptions that inform any definition of transgression have to do with (a) form or identity; (b) a movement or motion, a passage of some kind, and therefore implicitly a duration or temporality; and this passage from being on the side of the law to being lawless for example; hence trespass, to pass over or across, to infringe or impose; ( c) spatial and relational positions or locations (3)

The Garden of Eden is, for the most part, about characters coming to terms with pushing the boundaries of moral law. Interestingly, The Garden of Eden fulfills at least two of Wolfreys' common assumptions about transgression. The novel has to do with form and identity. Through a conscious decision to dress and get her hair cut like a boy, Catherine embodies the idea that form is identity. This ties back to my earlier reading of "The Battler" and Judith Butler's idea of sex being "constructed through a ritualized repetition of norms" (Bodies ix). The novel is also about transgressing spatial positions because the 
Bournes are on honeymoon in the off-season in communities of France and Spain that are not as socially progressive as the Bournes are. This is evident in David's thoughts about their gallivanting through Europe: "now there is the disregard of the established rules which can very well be the salvation of the whole coast. We are pioneers in opening up the summer's season which is still regarded as madness" (Garden of Eden 167). Finally, the novel is about relational positions, because men are not expected to be women or vice versa in the period's more conservative worldview, nor is it acceptable for a man to have two wives, or a woman to have a husband and a wife, as the characters in the novel do.

The novel starts off in France, where the newly-married Bournes are living in a hotel by the sea: "the hotel was on a canal that ran from the walled city... straight down to the sea... In the evenings and the mornings when there was a rising tide sea bass would come into it.... A jetty ran into the blue and pleasant sea" (3). The fact that the tides are mentioned is important and sets the stage for a transgressive reading of the text. Georges Bataille considered the ebb and flow of the sea as important to understanding human nature in terms of incretion and excretion. In "The Solar Anus," Bataille writes:

The simplest image of organic life united with rotation is the tide. From the movement of the sea, uniform coitus of the earth with the moon, comes the polymorphous and organic coitus of the earth with the sun. But the first form of solar love is a cloud raised up over the liquid element. The erotic cloud sometimes becomes a storm and falls back to earth in the form of rain, while lightning staves in the layers of the atmosphere. The rain is soon raised up again in the form of an immobile plant. (7) 
In other words, all elements of the world are united in a sexual nature that both gives and takes. The earth's interplay with the moon causes changes in tides, but the earth and moon's dance is dictated by the earth's relation to the sun, which gives light and heat and then takes it away. The Garden of Eden, then, with its study of human relations, could be considered a microcosm of activities that Bataille sees as happening on a cosmic level. Furthermore, Bataille's cosmic vision of "uniform coitus" is pointedly free from the concept of gendered identity. It is about fluidity, not definite roles, much like the sexual identities in Garden of Eden.

When Catherine Bourne states very early in the text that she is "the destructive type" (Garden of Eden 5) and will destroy David, she seems to be a prototypical villain. But the text seems to suggest that Catherine's anarchic nature is liberating and pleasing to David, and Bataille would argue that destruction is necessary for creation. The couple already looks very similar: "Most people thought they were brother and sister until they said they were married. Some did not believe that they were married and that pleased [Catherine] very much" (6). Catherine has a propensity to buck tradition and transgress societal mores, which is a credit to her character, a point to which I will return. To take their external similarity and make it even more pronounced, Catherine goes out and gets a male haircut that "was cut with no compromises. It was brushed back... but the sides were cut short and the ears... were clear and the tawny line of her hair was cropped close to her head and smooth" (15).

It is at this moment that the text becomes explicitly about interrogating and eventually neutralizing the male/female binary. Catherine is not the destructive type in 
the sense that she willfully hurts other people in the story. If anything is destroyed by Catherine's need to blur rigid definitions of sexual identity, it is David's view of what a male is supposed to be and do sexually and what a female is supposed to be and do sexually. Catherine says "I'm a girl. But now I'm a boy too and I can do anything and anything and anything," (15) to which David, not missing a beat, responds by calling her "brother" (15). This implies acceptance on David's part of Catherine's actions, and shortly he says "I like it" (15) which brings to mind the experimentation with haircuts in "Cat in the Rain." Moreover, while David's "I like it" could be simply in regards to the hair, it can also refer to Catherine's exploration (and destruction) of the male/female binary, since she acknowledges that she is both female and male.

The Garden of Eden is replete with depictions of sexual activity, which is in itself a far cry from most of Hemingway's other work. Sex (and sexual dysfunction) was only implied in The Sun Also Rises, and aside from the aforementioned subtle sexual activity such as the implied incest in "Soldier's Home" and possible homosexuality in "The Three-Day Blow" in In Our Time, Hemingway did not seem to be an author interested in depicting sex. This novel, however, is all about the transgressive quality of sex. After getting her boy's haircut, Catherine takes her experimentation one step further and penetrates David anally: "He lay there and felt something and then her hand holding him and searching lower and he helped with his hands and then lay back in the dark and did not think at all and only felt the weight and the strangeness inside" (17). Note that David helps Catherine, who is a consensual partner. Many critics ${ }^{3}$ have decried Catherine's

\footnotetext{
${ }^{3}$ Critic Meryl Altman calls Catherine "a controlling figure who manipulates" her husband David into the transgressive acts mentioned here, and goes as far as calling Catherine "evil" in her article "Posthumous
} 
impositions on David but the fact remains that in the moments right before any of the sexual acts in the novel David is always a willing participant. Furthermore, David is uncomfortable when Catherine introduces Marita into their relationship as an equal partner, but as the text progresses he seems to like the idea because it is so transgressive: "...he knew it was wrong to want them both but he did" (132).

In The Politics and Poetics of Transgression, Peter Stallybrass and Allon White attempt to map out social and symbolic hierarchies in language, literature and history, and analyze what transgression means in these particular areas that inform worldviews. These authors are interested in binary notions, especially the high and the low or the top and the bottom: “The 'top' attempts to reject and eliminate the 'bottom' for reasons of prestige and status, only to discover, not only that it is in some way frequently dependent upon that low-Other" (5) This idea of the top rejecting the bottom, only to realize it needs the bottom to exist, is the Hegelian Master-Slave dialectic. The authors further elaborate:

Also that the top includes that low symbolically, as a primary eroticized constituent of its own fantasy life. The result is a mobile, conflictual fusion of power, fear, and desire in the construction of subjectivity: a psychological dependence upon precisely those Others which are being rigorously opposed and excluded at the social level. It is for this reason that what is socially peripheral is so frequently symbolically central (like long hair in the 1960s). (5)

Queer: Hemingway Among Others.” Tamara M. Powell acknowledges broad critical distaste for Catherine, but goes a step further than the rest, asserting that Catherine is the archetypical dangerous/killer woman, Lilith, in her article "Lilith Started It! Catherine as Lilith in 'The Garden of Eden." 
Taking Stallybrass and Allon's model as a guide, it becomes clear that David (the partner with all the societal and relational power by virtue of gender) has this psychological dependency on Catherine because of her Otherness. Stallybrass and Allon's example of long hair as socially peripheral but symbolically central in the 1960 s parallels the short hair in the novel's time period, which is probably the 1920s.

Hemingway's aesthetic decisions in The Garden of Eden warrant further analysis. The aesthetic decision to create dialogue that is both simple and yet rife with possibility (which will be discussed further below) is a hallmark of Hemingway's style. However, The Garden of Eden is easily Hemingway's most experimental work, and it is postmodern in one sense because the author liberates himself to comment on the act of writing itself in a show of meta-awareness of the text. We see Hemingway's aesthetics repeated by David later in the text when he is thinking about his own writing: "It's all very well for you to write simply and the simpler the better. But do not start to think so damned simply. Know how complicated it is and then state it simply" (Garden of Eden 37). David is essentially summarizing Hemingway's famous "iceberg theory" of writing, whereby there is only a small fraction of the whole work visible on the surface. The conflicting emotions are left unstated, and it is up to the reader to fill in those gaps in the text. The most famous example of this stylistic decision in Hemingway's oeuvre is the final line of The Sun Also Rises: Jake Barnes replies to Lady Brett Ashley's grandiose ideas of what their relationship could have been like with the simple: "Isn't it pretty to think so?" (The Sun Also Rises 251) The reader knows that their relationship could have 
never worked because Jake suffered a crippling injury during the war that left him impotent.

In my introduction, I discussed Tom Lutz's view that an author's personal politics should not cloud the skill and openness with which an author depicts the world, giving value to the literary as art: "The 'effect of the real' they achieve, their wit, their affective power, and many other elements of their literary art are enabled by this multiplicity, this openness" (14). There are at least two moments in the text when David explicitly adheres as an author in his own right to Lutz's philosophy. Once, when he asks Marita about his work: "Is it all right? Can you smell the shamba smell and the clean smell of hut inside and feel the smoothness of the old men chairs?" (Garden of Eden 204) and once again, when he thinks to himself, "Thank God he was breaking through on the stories now. What had made the last book good was the accuracy of detail which made it believable" (211). Though the passage from Lutz quoted above is more focused on literary value as authorial openness to depicting a variety of voices, it is implicit that the details like the smell of the hut and the smoothness of the chairs are what make the voices viable. This is the "effect of the real" that Lutz mentions, and it is this effect that David seems to be most interested in.

The passages where David is writing his Africa story are possibly Hemingway at his most experimental, despite the typical, Hemingwayesque content of the stories. David begins writing and immediately becomes a part of that world:

He reread his careful legible hand and the words took him away and into the other country, he lost that advantage and was faced with the same 
problem and when the sun rose out of the sea it had, for him, risen long before and he was well into the crossing of the gray, dried, bitter lakes his boots now white with crusted alkalis. (138)

The language here is definitely playful, but also has a dizzying effect on the reader, because one is reading another character's descent into a story. Just like any reader of any book can "become" the protagonist, in this novel we see Hemingway playing with that sort of identification and forcing the reader to experience that readerly dissonance twice. There is a similar meta-awareness of the act of reading in To Have and Have Not, when Richard Gordon, a writer, sees Harry Morgan's wife crying on the street. The reader knows that she cries because Harry was injured, but Richard "had seen, in a flash of perception, the whole inner life of that type of woman" (To Have 177) and decides to write a story about how she was crying because her husband was unhappy with her and was cheating on her, which any reader of that novel knows is false. While these moments of aesthetic experimentation are not specifically gender-transgressive, the moment of readerly dizziness in The Garden of Eden should be taken as an example of an author who was not limited in the tools of his craft, but was constantly experimenting to get readers to feel something different, new, and avant-garde, which is a fundamental point of this thesis. These moments are also postmodern in their playfulness, and serve to further Hemingway's deconstruction of binary notions of thought. In these two cases, Hemingway seems to anticipate Roland Barthes' famed Death of the Author by acknowledging, especially in To Have and Have Not, that there is no one "right" message 
imbued in a text by an author-god, but many messages that the reader puts together based on his or her own experience.

The fact that Catherine says that because she has become a boy she can do anything merits some analysis. Hemingway has never been regarded as an author who is sympathetic to the plight of female characters. In fact, many of the females in his works seem to serve a limited purpose. Toni Morrison, whom I have previously mentioned as representative of the negative feelings many critics express towards Hemingway, argues that "some of the ... women in Hemingway's fiction who become objects of desire have the characteristics of nurses without the professional status" (81). In other words, most of the women (and, Morrison argues, some of the secondary male characters) serve to simply help along the flawed and usually racist white male protagonist and are not fullyfleshed characters in the text. The fact that Hemingway has a female character acknowledge the social and relational power that comes with being a man is a credit to him, and it is not an isolated event. We also see a woman somewhat unhappy with her lack of strength (both physical and relational) in To Have and Have Not: Harry Morgan insults a tourist who is sitting at a bar with his wife. The man says "I should have hit him, I guess... What do you think, dear?" to which the woman replies "I wish I was a man" (To Have 135). This semi-frequent acknowledgement of the relative social powerlessness of women in American society at the time is also evidence of the "postmodernist sensitivity" (sensitivity at least towards gender) that Morrison asserts Hemingway lacks. 
Catherine Bourne stands above Morrison's idea of a nurse figure because her sexually transgressive ways seem to bother David at some points (he usually refers to Catherine as "Devil") but, in what is the most important moment of reflection in the novel, David says to himself, "You've done that to your hair and had it cut the same as your girl's and how do you feel?... You like it.. Now go through with the rest of it whatever it is and don't ever say anyone tempted you or that anyone bitched you" (Garden of Eden 84). Despite his publicly enacted words of distaste for what happens David is brave enough to come to terms internally with enjoying being a woman in bed and dressing up to fulfill Catherine's fantasy of gender blending further (and, as stated, David helped Catherine penetrate him the first time). The fact that David publicly states his aversion to the his sexual activities with Catherine while internally accepting them brings to mind Judith Butler--David is acting in a certain way to construct his masculine identity before the only audience he has, which is at times Catherine and at times Marita. David's internal confession exonerates Catherine from any "wrongdoing" and, though David remains sarcastic and, at worst, condemnatory of Catherine (at one point suggesting she should be institutionalized), the veracity of David's internal monologue is unquestionable. Alone inside himself, he has nothing to prove to anyone or no one to act towards. Still, the passage is not without its problems: the use of the word "bitched" is of course derogatory toward women, but on some level that is balanced by the fact that David knows and enjoys that Catherine allows him to become a woman.

Toni Morrison asserts that the laborious process of darkening her skin is evidence of Catherine's (and by extension, Hemingway's) misappropriation of the African figure 
and the concept of Africanism: "Catherine [associates] blackness with strangeness, with taboo - understands also that blackness is something one can 'have' or appropriate" (87). There is some evidence for this in one racist statement that Catherine makes (which will be discussed below), but Catherine's conscious blurring of gender binaries is meant to be seen in a sympathetic light because it is something she cannot control. It seems to be an impulse from deep inside that has nothing to do with demonizing blackness. When Catherine says to David “...I broke myself in pieces in Madrid to be a girl and all it did was break me in pieces...You're a girl and a boy both and you really are. You don't have to change and it doesn't kill you and I'm not," (Garden of Eden 192) the reader is left pitying Catherine because there is no evil in her. If anything, her complaint could be evidence for a feminist reading of the text. Catherine could convincingly be read as a lesbian character stuck in an unhappy marriage with a man, especially in light of the following line of dialogue: “'I don't go in for girls' Catherine said. Her voice did not sound right either to herself or to David" (105). Although a feminist reading of the novel is not the goal of this project, the fact that Catherine can be read in so many different ways is further evidence of the exceptional nature of this female character in Hemingway's oeuvre.

Catherine could still be termed a villain for burning David's laboriously written story about Africa, but Hemingway the author seems to side with Catherine. When David begins to write his Africa story, the reader is placed in a prototypical Hemingway story: a boy is on a hunt in Africa and learns about injustice through the act of seeing an elephant hunted for ivory. This one-sentence summary sounds like it could be a story found in In 
Our Time; however, Hemingway the author allows Catherine to undercut David (who closely resembles Hemingway the author, at least in terms of both men's literary aesthetic, as established above) and question the usefulness of the limited and limiting story of Africa by a white author against the new, complicated, and socially questioning narrative about the Bournes' own marital experiences. In a particularly powerful passage that undercuts the famed Hemingway mythos, Catherine says to David:

Well write it then. It's certainly much more interesting and instructive than a lot of natives in a kraal or whatever you call it covered with flies and scabs in Central Africa with your drunken father staggering around smelling of sour beer and not knowing which ones of the little horrors he had fathered. (189)

Hemingway seems to preempt critics like Toni Morrison and Amy Strong who see in works like "Indian Camp" a problematic envisioning of race whereby white superiority is (unconsciously?) enforced through depictions of the "savagery" of minorities. Catherine's racism notwithstanding, this quoted passage is evidence of an avant-garde sensibility in Hemingway in that the author allows this passage, which questions anyone's, including his own, ability to represent (post)colonial reality into his text and also seems to stress that writing postcolonial texts is not as fruitful as writing a text like Garden of Eden, which is fundamentally about probing and pushing societal dictates and getting beyond the postcolonial.

The ending of the novel seems problematic. Critic Robert E. Fleming writes in "The Endings of Hemingway's Garden of Eden" that "anyone reading The Garden of 
Eden must be struck by the difference between the optimism of its final chapter and the ends of any other Hemingway novel" (261-2) and mentions the ending of The Sun Also Rises, which was discussed above. Fleming's article summarizes two other strands of the novel that were edited out by Scribner's, Hemingway's publishing house, and that involved other couples engaged in gender-bending and -blending activities both with and without the Bournes. Fleming is correct to point out the exaggeratedly happy ending when David, who shortly after his work was burned by Catherine told Marita that "When it's right you can't remember...They're gone" (Garden of Eden 230), is suddenly able to remember the glory of his words and retransmit them to the page:

You have three choices. Try to remember one that is gone and write it again. Second, you can try a new one. and third, write the god damned narrative. So, sharpen up and take the best one. you always gambled when you could bet on yourself. Never bet on anything that can talk, your father said and you said, Except yourself... So take the best one and write one new and good as you can. (238)

David chooses two options, and the one he ignores is the one that Catherine suggested, which would be to write the narrative about their experience. Though the character of David seems stuck in his old ways and therefore typically Hemingwayesque, Hemingway the author seems to want to break away from this view by giving readers the narrative about Catherine in a very self-aware style. Thus even the forced happy ending (or the other strands of the text that Fleming mentioned) all reflect the fact that what the actual reader is getting is the story that David was unable to face and write. Though Marita is a 
typical Hemingway "nurse" character, the fact that, even with this nurse who is meant to keep the troublingly racist and sexist white males in a static mental state, the story ends up being about a woman who is not a "nurse" and ends up proving to the typical Hemingwayesque character that it is important to document these transgressions is a credit to Hemingway's aesthetics. In this novel, Hemingway allows himself to voice more fully than he does elsewhere an alternative notion of racial/gender identity that is implicit through his most experimental fiction. 


\section{CONCLUSION}

Richard Fantina writes in "Hemingway's Masochism, Sodomy, and the Dominant Woman" that

Elements in much of Hemingway's work indicate a masochistic sensibility coexisting with his cult of traditional masculinity. As an artist, Hemingway expresses an alternative masculinity that on the surface seems diametrically opposed to that which he publicly embraced, but both paradigms of masculinity...now have a more recognized validity... Hemingway's embodiment of diverse models of masculinity may be his greatest legacy. (85)

It is telling that even in what is a straightforward psychological reading of Hemingway's work, the critic rightly focuses on Hemingway’s artistic choices. Hemingway’s artistic choices, as I have outlined them in this project, reveal a forward-thinking and experimental author whose entire oeuvre merits reevaluation.

I would like to close this thesis with one of David Bourne's reflections during the act of writing:

It was not him, but as he wrote it was and when someone read it, finally, it would be whoever read it and what they found when they should reach the escarpment...whoever read it would find what there was there and have it always. (Garden of Eden 129) 
The escarpment in question is a real locale in the Africa story, but I want to suggest that the escarpment is symbolic of a new level of Hemingway study, one focused on the aesthetic and not simply the biographical. This avenue of study will reveal an author that, though at times troublingly short-sighted in matters of race and gender in his work, was nevertheless attempting to make readers aware of several wrongs in the Western, binary system of thought that continued to dominate society in an excitingly transgressive aesthetic fashion. It is by re-engaging the aesthetic experimentation of Hemingway that we can discover this progressive strand to his work, and begin to see all of his works in a new and more appreciative light. 


\section{LIST OF REFERENCES}

Altman, Meryl. "Posthumous Queer: Hemingway Among Others." The Hemingway Review 30.1 (2010): 129-141. Print.

Baker, Carlos. "The First Forty-Five Stories.” Critical Insights: Ernest Hemingway. Ed. Eugene Goodheart. Hackensack: Salem Press, 2010. 71-98. Print.

Bataille, Georges. Visions of Excess: Selected Writings, 1927-1939. Ed. Allan Stoek1 Minneapolis: University of Minnesota Press, 1985. Print.

Berman, Ron. "Recurrence in Hemingway and Cezanne." Critical Insights: Ernest Hemingway. Ed. Eugene Goodheart. Hackensack: Salem Press, 2010. 139-156. Print.

Boulard, Garry. "'State of Emergency': Key West in the Great Depression." The Florida Historical Quarterly 67.2 (1988): 166-183. Print.

Butler, Judith. Bodies that Matter. New York: Routledge, 2011. Print.

--. "Performative Acts and Gender Constitution: An Essay in Phenomenology and Feminist Theory." Performing Feminisms: Feminist Critical Theory and Theatre. Ed. Sue-Ellen Case. Baltimore: Johns Hopkins University Press, 1990.

Fantina, Richard. "Hemingway's Masochism, Sodomy, and the Dominant Woman." The Hemingway Review 23.1 (2003): 84-105. Print.

Fleming, Robert. “The Endings of Hemingway's Garden of Eden." American Literature 61.2 (1989): 261-70. Print.

Gerogiannis, Nicholas. 'Nick Adams on the Road: 'The Battler' as Hemingway's Man on the Hill.” Critical Essays on American Literature. 1983: 176-188 Boston: G.K. Hall. Print.

Griffin, Peter. "A Foul Mood, A Dirty Joke: Hemingway's 'Cat in the Rain'." The Hemingway Review 20.2 (2001): 99-102. Academic OneFile. Web. 18 Sep. 2011.

Hegel, Wilhelm Friedrich. "Phenomenology of Spirit." The Norton Anthology of Theory and Critcism. Ed. Vincent B. Leitch. New York: W. W. Norton \& Company, 2001. 630-636. Print.

Hemingway, Ernest. The Complete Short Stories of Ernest Hemingway. New York: Scribner, 1987. Print.

---. The Garden of Eden. New York: Scribner, 1986. Print. 
---. The Sun Also Rises. New York: Scribner, 1954. Print.

--. To Have and Have Not. New York: Scribner, 1937. Print.

Hochman, Brian. "Ellison's Hemingways.” African American Review 42.3-4 (2008): 513. Print.

James, Ian. The Fragmentary Demand: An Introduction to the Philosophy of Jean-Luc Nancy. Standford: Stanford University Press, 2006. Print.

Jungman, Robert E. "Hemingway's To Have and Have Not." The Explicator 62.4 (2004): 224-227. Literature Resource Center. Web. 18 Sep. 2012.

Knott, Toni D. "Playing in the Light: Examining Categorization in To Have and Have Not as a Reflection of Identity or Racism." North Dakota Quarterly 64.3 (1997): 82-88. Rpt. in Twentieth-Century Literary Criticism. Ed. Janet Witalec. Vol. 138. Detroit: Gale, 2003. Literature Resource Center. Web. 21 Mar. 2011.

Lutz, Tom. Cosmopolitan Vistas: American Regionalism and Literary Value. Cornell: Cornell University Press, 2004.

Monteiro, George. "“This Is My Pal Bugs": Ernest Hemingway's The Battler." Studies In Short Fiction 23 (1986): 179-183. OmniFile Full Text Mega (H.W. Wilson). Web. 31 Aug. 2012.

Morrison, Toni. Playing in the Dark: Whiteness and the Literary Imagination. Cambridge: Harvard University Press, 1990. Print.

Nancy, Jean-Luc. Being Singular Plural. Stanford: Stanford University Press, 2000. Print.

Nesmith, Chris L. “'The Law of an Ancient God' and the Editing of Hemingway's Garden of Eden: The Final Corrected Typescript and Galley. The Hemingway Review 20.2 (Spring 2001): 16. Print.

Powel, Tamara M. "Lilith Started It! Catherine as Lilith in The Garden of Eden." The Hemingway Review 15.2 (1996): 78+. Literature Resource Center. Web. 18Sep 2012.

Raeburn, John. "Skirting the Hemingway Legend." American Literary History 1.1 (1989):206-218. Print.

Strong, Amy L. Race and Identity in Hemingway's Fiction. New York: Palgrave Macmillan, 2008. Print.

Stallybrass, Peter and Allon White. The Politics and Poetics of Transgression. New York: Cornell University Press, 1986. Print. 
Wolfreys, Julian. Transgression: Identity Space Time. New York: Palgrave Macmillan, 2008. Print. 